\title{
RESPON GURU DALAM PENDAMPINGAN PEMBUATAN MEDIA PERMAINAN
}

\author{
Oleh: \\ Laily Rosdiana', An Nuril Maulidha F.² \\ 1,2 Program Studi Pendidikan IPA, FMIPA Universitas Negeri Surabaya \\ 1'ailyrosdiana@unesa.ac.id
}

\begin{abstract}
Abstrak
Proses pembelajaran diselenggarakan secara interaktif, menyenangkan, menantang, inspiratif, memotivasi peserta didik untuk berpartisipasi aktif, serta memberikan ruang yang cukup bagi prakarsa, kreativitas, dan kemandirian sesuai dengan bakat, minat, kemampuan dan perkembangan fisik serta psikologis peserta didik. Berdasarkan hasil wawancara dengan salah satu guru IPA SMP di Kabupaten Jombang diketahui bahwa kemauan belajar siswa sangat rendah sehingga hasil belajar siswa dan pemahaman terhadap materi juga rendah. Hal tersebut dikarenakan guru hanya menyampaikan materi dengan ceramah dan presentasi sehingga siswa kurang termotivasi untuk belajar dan siswa lebih senang bermain. Memperhatikan hal tersebut diperlukan suatu media yang dapat mewadahi keluh kesah guru dalam bentuk tulisan agar kegiatan diskusi, masukan dari teman guru serumpun dapat berlangsung dengan lebih terbuka. Berdasar hasil angket pertanyaan positif dan negatif yang diberikan, didapatkan hasil persentase secara berturut- turut sebesar $93,3 \%$ dan $95 \%$, sehingga sebagian besar guru- guru peserta pelatihan merasa termotivasi untuk terus mengembangkan media- media yang dapat menunjang kegiatan belajar mengajar di sekolah, sehingga siswa tidak merasa jenuh dengan pelajaran dikelas serta senang karena dapat belajar sambil bermain. Dari angket tersebut dapat disimpulkan bahwa para peserta dapat memperoleh manfaat dari program pelatihan ini untuk meningkatkan kualitas media pembelajaran, mengetahui cara menggunakan media permainan, dan mampu membuat media pembelajaran sesuai dengan mata pelajaran yang diampu masingmasing peserta.
\end{abstract}

Kata Kunci: Media permainan

\begin{abstract}
The learning process is conducted in an interactive, fun, challenging, inspiring, motivating the students to actively participate and provide enough space for innovation, creativity, and independence in accordance with their talents, interests, abilities and physical and psychological development of learners. Based on the interview with one of the Junior High School science teacher in Jombang that the willingness of student to learning is low, that the effect of student learning and understanding of the material is low. This condition is caused by teachers are just presenting the material with lectures and presentations. Students are less motivated to learn and they enjoy playing in classroom. Noting this required a medium which can accommodate teachers' complaints in written form so that discussions and input from teachers allied friends can take place more openly. Based on the results of questionnaires positive and negative questions are given, the percentage of results obtained respectively by 93.3\% and 95\%, so most teachers trainees feel motivated to continue to develop media- media that can support teaching and learning in schools, so that students do not feel bored with the lessons in class and delighted to learn while playing. From the questionnaire it can be concluded that the teachers trainees can benefit from this training program to improve the quality of learning media, knowing how to use the media game, and are able to make learning media in accordance with the subject of teaching each teachers trainees.
\end{abstract}

Keywords: Game media 


\section{PENDAHULUAN}

Permendikbud Nomor 103 tahun 2014, Pembelajaran adalah proses interaksi antar peserta didik, antara peserta didik dengan tenaga pendidik dan sumber belajar pada suatu lingkungan belajar. Proses pembelajaran diselenggarakan secara interaktif, menyenangkan, menantang, inspiratif, memotivasi peserta didik untuk berpartisipasi aktif, serta memberikan ruang yang cukup bagi prakarsa, kreativitas, dan kemandirian sesuai dengan bakat, minat, kemampuan dan perkembangan fisik serta psikologis peserta didik.

Kegiatan pembelajaran yang dilakukan oleh guru perlu menggunakan prinsip yang: (1) berpusat pada peserta didik, (2) mengembangkan kreativitas peserta didik, (3) menciptakan kondisi menyenangkan dan menantang, (4) bermuatan nilai, etika, estetika, logika, dan kinestetika, dan (5) menyediakan pengalaman belajar yang beragam melalui penerapan berbagai strategi dan metode pembelajaran yang menyenangkan, kontekstual, efektif, efisien, dan bermakna (Kemendikbud, 2013), sehingga pembelajaran yang menyenangkan dapat memberi rasa aman, nyaman dan asyik pada siswa. Menurut Mulyati (dalam Meilia, 2013) struktur kognitif yang diperoleh siswa sebagai hasil dari proses belajar akan lebih bermakna, stabil dan tersusun secara relevan sehingga akan terjaga dalam ingatan, maksudnya dengan bermain dan pengalaman langsung dapat menyebabkan ingatan siswa terhadap materi yang dipelajari akan bertahan lama dan meteri yang dipelajari akan terkenang oleh siswa. Hal ini akan memudahkan siswa untuk mengingat kembali apa yang telah dipelajarinya jika siswa dihadapkan pada suatu masalah. Selain itu, Permainan dapat menjadi sumber belajar atau media belajar apabila permainan tersebut bertujuan untuk mencapai tujuan pendidikan atau pembelajaran (Sadiman, 2014).

Berdasarkan hasil wawancara dengan salah satu guru IPA SMP di Kabupaten Jombang diketahui bahwa kemauan belajar siswa sangat rendah sehingga hasil belajar siswa dan pemahaman terhadap materi juga rendah. Hal tersebut dikarenakan guru hanya menyampaikan materi dengan ceramah dan presentasi sehingga siswa kurang termotivasi untuk belajar dan siswa lebih senang bermain. Maka dari itu, sekolah dan siswa membutuhkan media yang dapat memotivasi siswa untuk belajar sambil bermain. Media yang digunakan tidak hanya media peraga saja melainkan media yang lainnya seperti media visual atau media permaianan.

Memperhatikan hal tersebut diperlukan suatu media yang dapat mewadahi keluh kesah guru dalam bentuk tulisan agar kegiatan diskusi, masukan dari teman guru serumpun dapat berlangsung dengan lebih terbuka. Jadi kegiatan pendampingan Pembuatan Media Permainan Bagi GuruGuru IPA SMP di Kabupaten Jombang perlu dilakukan.

Berdasarkan analisis situasi dan tinjauan beberapa buku terkait tuntutan Permendikbud Nomor 103 tahun 2014 tersebut dapat dikatakan bahwa guru-guru IPA SMP di Kabupaten Jombang masih belum sepenuhnya memahami pembuatan media permainan dalam proses belajar mengajar. Para guru masih belum terampil dalam membuat media permainan yang dapat melatihkan keterampilan bekerjasama siswa dalam proses belajar mengajar di kelas. Pemanfaatan sarana/prasarana yang tersedia di sekolah belum maksimal dan belum sepenuhnya dikaitkan dengan media yang digunakan dalam pembelajaran. Sementara itu, Undang-undang Nomor 12 Tahun 2012 tentang Pendidikan Tinggi Pasal 45 mengemukakan bahwa salah satu kewajiban Perguruan Tinggi adalah menyelenggarakan pengabdian kepada masyarakat yang memanfaatkan IImu Pengetahuan dan Teknologi untuk memajukan kesejahteraan masyarakat dan mencerdaskan kehidupan bangsa. Dengan demikian dosen sebagai pendidik professional dan ilmuwan memiliki tugas utama untuk mentransformasi, mengembangkan, dan menyebarluaskan IImu Pengetahuan dan Teknologi melalui kegiatan Pengabdian kepada Masyarakat (PKM).

Kegiatan PKM yang akan dilakukan adalah kegiatan PKM untuk menyelesaikan permasalahan yang terjadi di sekolah-sekolah menengah pertama di Kabupaten Jombang, yaitu melaksanakan kegiatan pendampingan pembuatan media permainan bagi guru-guru SMP Kabupaten Jombang untuk menunjang kegiatan pembelajaran yang sesuai dengan harapan. Guru-guru yang mengikuti pelatihan ini adalah guru-guru dari berbagai SMP Kabupaten Jombang yang ditunjuk oleh Dinas Pendidikan Kabupaten Jombang atas rekomendasi Kepala Sekolah. Guru-guru ini nantinya diharapkan dapat menyebarluaskan pada kolega mata pelajaran lainnya yang ada di sekolah ataupun di lain sekolah. 
Permasalahan yang ingin dijawab dalam kegiatan PKM ini adalah adalah bagaimana respon guru- guru setelah dilaksanakan kegiatan PKM Pendampingan Pembuatan Media Permainan.

\section{METODE PELAKSANAAN}

Kegiatan PKM yang telah dilaksanakan memiliki target akhir yaitu respon guru-guru peserta workshop setelah mengikuti kegiatan pendampingan dan dapat diterapkan di sekolah masing-masing.

Indikator keberhasilan kegiatan PKM ini adalah jika respon guru- guru peserta pendampingan merespon positif kegiatan yang dilaksanakan dengan metode pendampingan sebagai berikut.

1. Memberikan materi tentang fungsi dan karekteristik media permainan

2. Workshop pembuatan media permainan

3. Review media permaianan karya guru oleh Tim Pelaksana PKM

Kegiatan Pengabdian kepada Masyarakat ini menggunakan sarana dan prasarana yang ada di Jurusan IPA FMIPA Unesa dan MGMP Kabupaten Jombang. Sebelum kegiatan dilaksanakan, Jurusan IPA FMIPA Unesa telah menyediakan sumber-sumber yang berguna dalam penyajian materi tentang Pembuatan Media Permainan dan beberapa contoh Media Permaianan yang sudah layak dan bisa diterapkan di sekolah karena sudah diteliti oleh para mahasiswa Jurusan IPA dalam penyusunan skripsi.

Tim PKM yang melaksanakan kegiatan berasal dari Jurusan IPA yang mempunyai pengalaman dalam membimbing mahasiswa yang salah satunya adalah pembuatan Media Permainan.

\section{HASIL DAN PEMBAHASAN}

Untuk menjaring respon peserta terhadap kebermanfaatan dan kebermaknaan program ini dilakukan evaluasi respon terhadap kegiatan pelatihan. Hasil Respon Guru Peserta Pendampingan Pembuatan Media Permainan dapat dilihat pada Tabel 1.

Tabel 1. Respon Guru Peserta Pendampingan Pembuatan Media Permainan

\begin{tabular}{cccccc}
\hline \multicolumn{7}{c}{ Pertanyaan } \\
\hline No. & Positif & $\%$ & No. & Negatif & $\%$ \\
\hline 1 & 20 & 100 & 4 & 18 & 90 \\
\hline 2 & 20 & 100 & 7 & 18 & 90 \\
\hline 3 & 17 & 85 & 10 & 20 & 100 \\
\hline 5 & 17 & 85 & 13 & 20 & \\
\hline 6 & 17 & 85 & & & \\
\hline 8 & 20 & 100 & & \\
\hline 9 & 20 & 100 & & & \\
\hline 11 & 17 & 85 & & & \\
\hline 12 & 20 & 100 & & & \\
\hline \multicolumn{7}{c}{ Rata-rata } & 93,3 &
\end{tabular}

Berdasar Tabel 1 dapat dilihat bahwa dari pertanyaan positif dan negatif yang diberikan, didapatkan hasil persentase secara berturut- turut sebesar $93,3 \%$ dan $95 \%$. Berdasar hasil pertanyaan angket respon, sebagian besar guru peserta pelatihan merasa termotivasi untuk terus mengembangkan media- media yang dapat menunjang kegiatan belajar mengajar di sekolah, sehingga siswa tidak merasa jenuh dengan pelajaran dikelas serta senang karena dapat belajar sambil bermain. Dari angket tersebut dapat disimpulkan bahwa para peserta dapat memperoleh manfaat dari program pelatihan ini untuk meningkatkan kualitas media pembelajaran, mengetahui cara menggunakan media permainan, dan mampu membuat media pembelajaran sesuai dengan mata pelajaran yang diampu masingmasing peserta.

Kegiatan Pengabdian pada Masyarakat ini telah terlaksana dengan baik berkat 
dukungan berbagai faktor yaitu: Komunikasi antar anggota tim berlangsung lancar dan efektif sehingga koordinasi tim pada proses persiapan, pembagian tugas, pelatihan dan simulasi dapat berlangsung dengan baik dan tepat waktu, peserta pelatihan yang terdiri dari guru-guru Sekolah Menengah Pertama di wilayah Kabupaten Jombang sangat antusias dan bersemangat dalam mengikuti pelatihan dari awal hingga akhir. Begitu pula saat penugasan dimana guru-guru tersebut diminta untuk membuat sendiri media pembelajaran sesuai dengan mata pelajaran masing-masing dengan penerapan media permainan, mereka sangat bersemangat untuk bekerja dan bertanya.

Adapun faktor penghambat adalah keterbatasan dana, sehingga hanya 13 sekolah saja yang dapat diikutsertakan dalam pelatihan ini, itupun hanya beberapa guru saja yang menjadi wakil dari sekolah serta waktu yang terbatas disebabkan oleh terbatasnya anggaran pula, disamping itu pelaksanaan pelatihan dilaksanakan menjelang bulan puasa sehingga harus segera diselesaikan.

\section{SIMPULAN DAN SARAN}

Berdasarkan uraian di atas dapat disimpulkan bahwa kegiatan yang telah dilakukan oleh tim pelaksana PKM telah berhasil menjawab permasalah di Dinas Pendidikan Kabupaten Jombang tentang guru- guru IPA belum bisa memotivasi siswa untuk belajar sudah bisa teratasi dengan adanya respon positif dari semua guru dan termotivasinya guru untuk membuat media permainan dalam proses pembelajaran.

Berdasar hasil pelaksanaan kegiatan pengabdian kepada masyarakat ini dan uraian pembahasan di atas, dapat disimpulkan beberapa hal sebagai berikut ini.

1. Pelatihan ini memberikan beberapa materi yang terkait dengan upaya meningkatkan kualitas pembelajaran dengan pemberian pengetahuan mengenai pemanfaatan media permainan yang menarik bagi siswa
2. Materi yang disajikan dapat diterima, dicerna, dan dipahami peserta dengan baik.

3. Kegiatan berlangsung lancar, tepat waktu dan sesuai dengan yang diharapkan.

Beberapa saran yang diusulkan untuk kegiatan PKM selanjutnya adalah sebagai berikut.

1. Waktu kegiatan pembuatan media permainan yang disediakan lebih lama agar kegiatan berjalan lebih efektif untuk menghasilkan media permainan sesuai yang diinginkan

2. Kegiatan pendampingan ini sebaiknya dilaksanakan sebelum tahun ajaran baru dimulai sehingga guru langsung dapat membuat media permaianan sesuai dengan perencanaan pembelajarannya dapat diterapkan untuk dievaluasi dari sisi kepraktisannya

\section{DAFTAR PUSTAKA}

Direktorat Pembinaan Pendidikan Tenaga Kependidikan dan Ketenagaan Perguruan Tinggi (2012), Peningkatan Kualitas Pembelajaran. Jakarta

Kemendikbud (2013). Bahan Uji Publik Kurikulum 2013.

Meilia, dike. 2013. "Penggunaan Media Ular Tangga Dike Untuk Meningkatkan Hasil Belajar Siswa". Jurnal antologi pgsd bumi siliwangi. Vol. I(1): hal. 3.

Peraturan Menteri Pendidikan Dan Kebudayaan Republik Indonesia nomor 103 tahun 2014 tentang pembelajaran pada Pendidikan Dasar Dan Pendidikan Menengah. 2014. Jakarta: Permendikbud.

Sadiman, Raharjo, Anung Haryono, Dan Harjito. 2014. Media pendidikan: pengertian, pengembangan, dan pemanfaatannya. Jakarta: PT. Raja Grafindo Persada. 